\title{
Adaptability and leaf anatomical features in oil palm seedlings produced by embryo rescue and pre-germinated seeds
}

\section{Zanderluce G. Luis', Kadja Milena G. Bezerra' and Jonny Everson Scherwinski-Pereira ${ }^{2 *}$}

\author{
${ }^{1}$ Universidade de Brasília, Instituto de Biologia, Campus Universitário Darcy Ribeiro, CEP 70910-900 Brasília, DF. \\ ${ }^{2}$ Embrapa Recursos Genéticos e Biotecnologia, Av. W5 Norte (final), CEP 70770-917 Brasília, DF. \\ *Corresponding author: jonny@cenargen.embrapa.br
}

Received: 20 September 010; Accepted: 12 November 2010

\begin{abstract}
Changes in the leaf structure of plants grown in different conditions have been reported, such as increase in size and density of stomata and reduction in stomatal control, amount of epicuticular wax, and mesophyll thickness, with a high diversity of intercellular spaces. However, these changes are highly variable depending on the physiological and morphological characteristics of each species. The objective of this work was to analyze the adaptability and anatomical plasticity of oil palm seedlings produced after embryo rescue and pre-germinated seeds. Expanded leaves were prepared for evaluation of morphometric data and anatomical structures. It was verified that the environmental conditions in vitro negatively influenced the stomata density, epidermal and hypodermal thickness, and the values for the expansion cells and leaf mesophile. Anatomically, the oil palm leaves present the same tissues composition in both growth conditions, with uniseriate epidermal cells, and tetracitic stomata occurring in both epidermal surfaces. Epidermal cells from in vitro plants are thinner than ones from greenhouse. The midrib of leaves from greenhouse plants are more developed and is composed by only one central vascular bundle, while plants from in vitro cultivation developed three to four collateral vascular bundles.
\end{abstract}

Key words: Elaeis guineensis, Arecaceae, germination, embryo culture, acclimatization, plantlets metabolism.

\section{RESUMO}

Adaptabilidade e características anatômicas de folhas em mudas de dendezeiros produzidas pelo resgate de embriões e sementes pré-germinadas.

Alterações na estrutura da folha de plantas crescidas em diferentes ambientes têm sido relatadas, como 0 aumento no tamanho e densidade dos estômatos e a redução no controle estomático, na quantidade de cera epicuticular e na espessura do mesofilo, com alta diversidade de espaços intercelulares. Entretanto, tais alterações são altamente variáveis em função das características fisiológicas e morfológicas próprias de cada espécie. 0 objetivo deste trabalho foi analisar a adaptabilidade e plasticidade anatômica foliar de mudas de dendezeiros produzidas pelo resgate de embriões e sementes pré-germinadas cultivadas num sistema in vitro ou em casa de vegetação. Cortes transversais e paradérmicos, além da dissociação de tecidos, foram preparados para obtenção dos dados morfométricos e anatômicos. Verificou-se que as condições ambientais do cultivo in vitro influenciaram negativamente os valores da densidade estomática, espessura da epiderme e hipoderme, e os valores obtidos para as células de expansão e 
do mesofilo foliar. Anatomicamente as folhas de dendezeiro apresentam a mesma composição tecidual em ambas condições de cultivo, com epiderme unisseriada, estômatos do tipo tetracítico de ocorrência em ambas as faces epidérmicas. As células epidérmicas das folhas de plantas in vitro são mais delgadas que as da casa de vegetação. Nas plantas de casa de vegetação a nervura principal é mais desenvolvida sendo formada por apenas um grande feixe vascular, enquanto que plantas cultivadas in vitro desenvolveram de três a quatro feixes vasculares.

Palavras-chave: Elaeis guineensis, Arecaceae, germinação, cultivo de embriões, aclimatização, metabolismo de plântulas.

\section{INTRODUCTION}

The African oil palm (Elaeis guineensis) is a monocot oilseed plant, perennial and allogamous, grown mostly in tropical regions such as Latin America, Southeast Asia, and Africa. This oil palm species is native from the northwestern region of Africa (Guinea-Bissau) and belongs to the Arecaceae family (Konan et al., 2006). Another important oil palm species - though native to the Americas - is Elaeis oleifera (Kunth; Cortés), which is called the "caiaué" palm in Brazil.

Despite having some desirable agronomic traits, such as a short stature and resistance to Lethal Yellowing Disease and Fusarium (the two major diseases of this crop), E. oleifera is not considered economically viable when compared to $E$. guineensis because its oil yield is lower. However, E. oleifera is fairly indicated and utilized in species-improvement programs because, despite geographically distant in origin, these two species are compatible in crossbreeding and generate fertile hybrids (Chia et al., 2009). Extensive germplasm collections of the American oil palm (E. oleifera) were made throughout the Amazon River Basin by the Brazilian agricultural research agency Embrapa (Empresa Brasileira de Pesquisa Agropecuária) and the IRHO (Institut de Recherches pour les Huiles et Oleagineux, France) in the mid-1980s, becoming an invaluable source of genetic material. Currently, genetic improvement programs for African oil palm (Elaeis guineenis) have sought the introgression of genes of interest present in germplasm from the American oil palm (Elaeis oleifera). Thus, elite plants of $E$. guineensis and $E$. oleifera have been crossed in order to obtain F1 hybrids with good productivity, shorter stature and resistance to disease (Barcelos et al., 2002; Chia et al., 2009; Scherwinski-Pereira et al., 2010).

However, the viability of the seeds of such crosses is very low. In some crosses, only around $30 \%$ of these seeds germinate spontaneously, even after undergoing treatment to break dormancy. To obtain a sufficient number of F1 plants in order to accelerate the achievement of goals of Embrapa's Oil Palm Genetic Improvement Program, in vitro embryo rescue experiments are being carried out towards the establishment of an effective protocol for asexual multiplication of selected hybrid plants.

Growing embryos in vitro is a promising technique for advancing knowledge on certain species because, based on such activity, it is possible to reproduce and study embryonic development, the breaking of dormancy, and especially the production of plants (Hu and Ferreira, 1998). Furthermore, growing palm tree embryos that normally have a low or slow germination process can be extremely useful for obtaining plants in a shorter time (Scherwinski-Pereira et al., 2006). This technique, besides having major importance as an alternative method for rapid plant propagation, makes it possible to elucidate aspects of development physiology under in vitro conditions, and may be used as a model for the optimization of the growth factors of plants originating from micropropagation, in the same way that it provides seedlings under uniform and sterile conditions for efforts of tissue growth. It also permits us to overcome the dormancy in certain types of seeds and, as a primary tool for improvement, to rescue immature hybrid embryos from incompatible crosses in which there are sexual barriers in the formation of seeds (Hu and Ferreira, 1998).

Anatomical studies of the genus Elaeis are rare, but examples include the contributions of Jourdan and Rey (1997), Adam et al. (2005), and Henderson (2006). Almost all of the existing works are geared toward genetic improvement, demonstrating the need for further studies geared toward anatomy, particularly foliar analysis of plants produced in vitro, because by means of such analyses it is possible to know and quantify the species own physiological characters.

Several structural changes have been found in leaf of plants grown in vitro conditions in comparison to that grown ex vitro, such as increase in size and density of stomata and 
reduction in stomatal control, amount of epicuticular wax, and mesophyll thickness, with a high proportion of intercellular spaces. However, the prevalence of each one of these changes is highly variable depending on the characteristics of each species, and the quantification thereof may help to improve conditions for growing plants. Based on the widely-known susceptibility of the leaves and morphological/anatomical variations in the plant-environment relation (Lee et al., 1997), this study was aimed at characterizing and analyzing the leaf anatomical plasticity of African oil palm seedlings formed from the rescue and cultivation of zygotic embryos in vitro and the germination of pre-germinated seeds in greenhouse.

\section{MATERIAL AND METHODS}

Fully expanded leaves were collected from oil palm plants at seven months of age, formed and maintained under in vitro and ex vitro (greenhouse) conditions. To better characterize the anatomic changes produced under different growing conditions, plants under in vitro culture were obtained from the rescue of zygotic embryos, and plants under exvitro conditions were obtained through cultivation of pregerminated seeds (Nunes et al., 1998), from material that was kindly provided by the Genetic Breeding Program of Embrapa Amazônia Ocidental, located at Manaus, Amazonas state, Brazil.

For in vitro germination of zygotic embryos of the African oil palm, the first step was seed sterilization, carried out by immersion in $70 \%$ alcohol for 3 min in a laminar flow chamber, followed by another $20 \mathrm{~min}$ immersion in a $50 \%$ commercial sodium hypochlorite solution (2.0-2.5\% active chlorine), plus one drop of Tween-20 for every $100 \mathrm{~mL}$ of this solution. Then the seeds were rinsed three times with deionized water, and properly autoclaved to remove any excess bleach.

After disinfection, the seeds were hydrated by immersion in deionized water for 24 hours to facilitate removal of the embryos from the seeds. Embryos were isolated using a scalpel and forceps, two incisions were made at a roughly $45^{\circ}$ angle in opposite directions around the embryo. Once isolated, the embryos were immediately inoculated in MS $1 / 2$ medium, plus biotin and pantothenic acid, $3 \%$ sucrose and $0.25 \%$ phytagel. The pH of the culture medium was adjusted to $5.8 \pm 0.1$ before adding the gelling agent. The culture medium was autoclaved at $121^{\circ} \mathrm{C}$ at a pressure of $1.3 \mathrm{~atm}$ for 15 $\min$. The test tubes $(25 \times 150 \mathrm{~mm})$ containing $10 \mathrm{~mL}$ of the culture medium were closed with aluminum foil, sealed with transparent PVC film, and stored under darkness in a growth chamber at a temperature of $25 \pm 2^{\circ} \mathrm{C}$ until the early formation of leaf primordia (1-2 $\mathrm{cm}$ in length), at which time they were placed under light ( $30 \mu \mathrm{molm}^{-2} \mathrm{~s}^{-1}, 16-\mathrm{hr}$ photoperiod), remaining under such conditions for seven months. Plants derived from in vitro culture were obtained using a standard production process for palm seedlings, by planting pregerminated seeds prepared by the dry heat method (Nunes et al., 1998). The pre-germinated seeds were placed in plastic bags $(20 \times 30 \times 30 \mathrm{~cm})$ containing a Plantmax $®$ substrate and kept in a climate-controlled greenhouse for up to seven months, when samples were collected for analysis.

For the analysis, cross sections of leaves were collected by hand, clarified according to Kraus and Arduin (1997), stained with Alcian Blue-Safranin at a ratio of 4:1 (v/v). In order to study the leaf epidermis, dissociation of tissues was carried out through the Ghouse and Yunus (1972) technique, using methylene blue staining. Photomicrographs of all sections were obtained with the aid of Motic BA300 microscope connected to a digital camera.

Six leaves originating from different individuals were evaluated for each growth conditions, and five fields with an area of $1 \mathrm{~mm}^{2}$ were selected at random. For each field, quantification was performed in order to obtain the stomatal density, trichome density, thickness of the mesophyll tissues and of the leaf blade, resulting in 30 measurements for each environmental condition.

Quantitative data were obtained using Image-Pro Plus 4.5 software. The data were statistically evaluated and submitted to analysis of variance the averages were compared by the Tukey test at $5 \%$ probability. The data regarding the count were transformed according to the square root of $x+1$.

\section{RESULTS AND DISCUSSION}

The leaf of Elaeis guineensis in both growth conditions analyzed (in vitro and greenhouse) has uniseriate epidermis, consisting of ordinary epidermis cells, with convex outer periclinal walls (Figure $1 A$ ). In paradermal section, the cells have straight walls and a tabular format (Figure 1B). Studies carried out by Bone et al. (1985) suggested that the curvature 
evidenced in the epidermal cell walls increases the leaf's efficiency to capture light energy, increasing the luminous flux within that organ and thereby facilitating photosynthesis and plant growth.

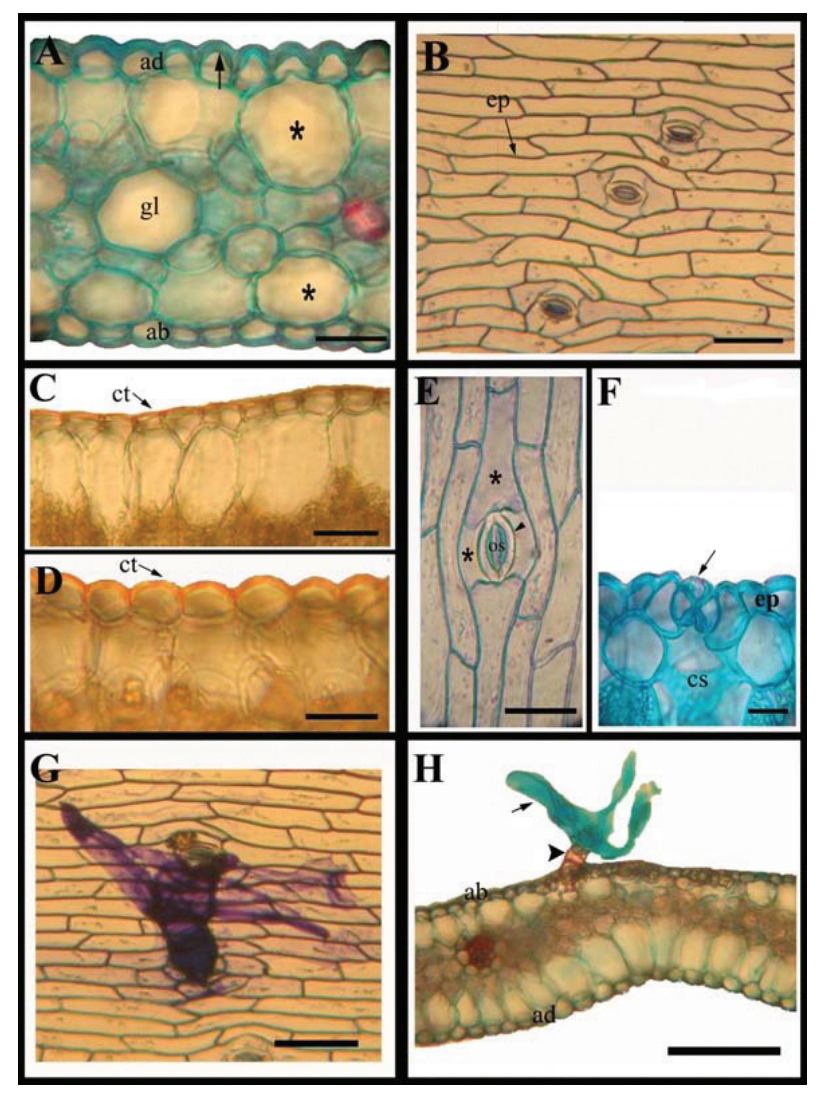

Figure 1. Transversal (A, C, D, F and $H$ ) and paradermal (B, E and G) sections of leaves from oil palm seedlings under in vitro and greenhouse conditions. (A) homogeneous mesophyll showing the adaxial epidermis (ad) with external convexes wall (arrow), hypodermis $\left(^{*}\right)$, internal secretory ducts ( $\mathrm{gl}$ ) and abaxial epidermis (ab). (B) tabular epidermal cells and straight walls (arrow). (C) leaf epidermis from in vitro oil palm seedlings with thin cuticle (arrow). (D) leaf epidermis from greenhouse oil palm seedlings with thickness cuticle (arrow). (E) tetracytic stomata, subsidiary cells $\left({ }^{*}\right)$, guard cells (arrowhead), and stomata aperture (os). (F) stomata (arrow) in the same level than epidermal cells (ep), substomatic chamber (cs). (G and H) multicellular and branche tector trichomes along of epidermis; basal cell (head arrow) and apical cell (arrow). Bars: A, C, D e F $=20 \mu \mathrm{m} ; \mathrm{B}, \mathrm{G} \mathrm{e} \mathrm{H}=$ $50 \mu \mathrm{m} ; \mathrm{E}=30 \mu \mathrm{m}$.

The epidermal cells of the in vitro leaves are coated with a thin layer of cuticle (Figure 1C), while those from the greenhouse (Figure 1D) show this layer significantly thicker (Table 1). The increased thickness of the cuticle on the leaf may play different roles related to plant protection and resistance. This structure may reduce the leaf digestibility by herbivorous, limit the pathogens transit in infected plants, reduce exudation of nutrients and other substances required in the early stages of development of the pathogens, as well as facilitate the acclimatization process of in vitro plants (Akin and Robinson, 1982; Rathi, 1998). It is likely that the higher exposition of plants grown in greenhouse to environmental elements can induce the cuticle enhancement.

Table 1. Morphometric and anatomical characteristics of leaves from oil palm seedlings produced by embryo rescue and pre-germinated seeds into different environments

\begin{tabular}{lcc}
\hline \multirow{2}{*}{ Parameters } & \multicolumn{2}{c}{ Environment } \\
\cline { 2 - 3 } & In vitro & Greenhouse \\
\hline Abaxial cuticle thickness $(\mu \mathrm{m})$ & $0.7 \mathrm{~A}$ & $1.1 \mathrm{~B}$ \\
Adaxial cuticle thickness $(\mu \mathrm{m})$ & $1.8 \mathrm{~A}$ & $3.4 \mathrm{~B}$ \\
Stomatal density on the abaxial surface $\left(\mathrm{mm}^{2}\right)$ & $57.6 \mathrm{~A}$ & $92.8 \mathrm{~B}$ \\
Stomatal density on the adaxial surface $\left(\mathrm{mm}^{2}\right)$ & $11.8 \mathrm{~A}$ & $14.8 \mathrm{~B}$ \\
Guard cells length $(\mu \mathrm{m})$ & $27.7 \mathrm{~A}$ & $25.9 \mathrm{~B}$ \\
Guard cells width $(\mu \mathrm{m})$ & $18.0 \mathrm{~A}$ & $15.2 \mathrm{~A}$ \\
Stomatal pore width $(\mu \mathrm{m})$ & $8.8 \mathrm{~A}$ & $7.4 \mathrm{~B}$ \\
Trichome density on the abaxial surface $\left(\mathrm{mm}^{2}\right)$ & $4.0 \mathrm{~A}$ & $3.9 \mathrm{~A}$ \\
Trichome density on the adaxial surface $\left(\mathrm{mm}^{2}\right)$ & $4.8 \mathrm{~A}$ & $4.4 \mathrm{~A}$ \\
Expansion tissue length $(\mu \mathrm{m})$ & $45.5 \mathrm{~A}$ & $75.6 \mathrm{~B}$ \\
Chlorenchyma thickness $(\mu \mathrm{m})$ & $39.9 \mathrm{~A}$ & $112.7 \mathrm{~B}$ \\
Leaf sheath thickness $(\mu \mathrm{m})$ & $107.7 \mathrm{~A}$ & $208.8 \mathrm{~B}$ \\
\hline
\end{tabular}

Means following by different letters within each evaluated parameter differ for the Tukey's test $(P \leq 0.05)$.

Stomata are important structures responsible for gas exchange of plant primordia in the processes of photosynthesis and respiration. In the leaves of the African oil palm, the stomata are the tetracytic type (Figure 1E) and flush with the other epidermal cells (Figure 1F). These occur on both surfaces, arranged and organized in longitudinal rows, with higher density on the abaxial surface (Table 1), classifying these leaves as amphihypostomatic. According to Tomlinson (1990), these types of stomata are characteristic to few families of Liliopsida, including Arecaceae and Cyperaceae.

Statistical analysis revealed significant differences in average density of stomata/ $/ \mathrm{mm}^{2}$, width and length of guard cells, and opening of the stomatal pore between the growths conditions analyzed (Table 1). In vitro leaves showed, on average, $58.0 \mathrm{~mm}^{-2}$ stomata on the abaxial surface and $11.9 \mathrm{~mm}^{-2}$ on the adaxial surface, whereas for the greenhouse leaves, the values were $92.8 \mathrm{~mm}^{2}$ and $14.8 \mathrm{~mm}^{2}$, respectively. This difference is probably due to 
the low availability of water and exposure to high radiance in greenhouse environment, which may increase up to $50 \%$ the stomatal density (Bosabalidis and Kofidis, 2002). The size of the stomata, as well as the opening thereof, is subject to large variations in consequence of environmental peculiarities, demonstrating the ability of plants to alternate this characteristics arising from environmental conditions in which the plant is developing (Pearce et al., 2005). The quantity, distribution, size, shape and mobility of the stomata are characteristics specific to each species, and may change in virtue of adaptations to environmental conditions (such as humidity, temperature and light) that the leaf is subjected to during the period of cell division and elongation. Such changes may affect the photosynthetic efficiency and, consequently, the plant growth (Muchow and Sinclair, 1989).

In oil palms, we observed multicellular and branched tector trichomes along the adaxial and abaxial surfaces of the epidermis (Figure $1 \mathrm{G}$ and $\mathrm{H}$ ). The trichomes, as observed to the cuticle and stomata, may also be susceptible to variations depending on the conditions to which the plants are exposed (e.g., Ellis, 1976; Silva et al., 2005). However, no significant differences were found in the trichomes disposition on leaves of oil palms exposed to the two growth conditions tested (Table 1).

Beneath the epidermis, on both leaf surfaces, it was observed the occurrence of a more developed hypodermis (Figures $1 \mathrm{~A}$ and 2) on the adaxial side, consisting of a layer of colorless cells and larger than the epidermal cells (Figure 2). This feature was also addressed in other palm species such as Asterogyne martiana (Stauffer et al., 2003), but only on the abaxial surface. According to Tomlinson (1990), the hypodermis is more developed in palms which evolved in arid environments and generally absent in plants native from shaded environments. Cells containing calcium oxalate crystals in the form of raphides were found in the hypodermis (Figure 2B) and chlorenchyma (Figure 2C) of the leaves grown in vitro and in a greenhouse; the same was observed by Chaimsohn et al. (2008) in Bactris gasipaes. Tomlinson (1990) and Zona (2004) reported that the occurrence of these crystals is common in all organs of palm trees, and that they rarely occur in the roots. According to Esau (1972), there is often the presence of raphides in all orders of monocotyledons, except in Alistematidae.

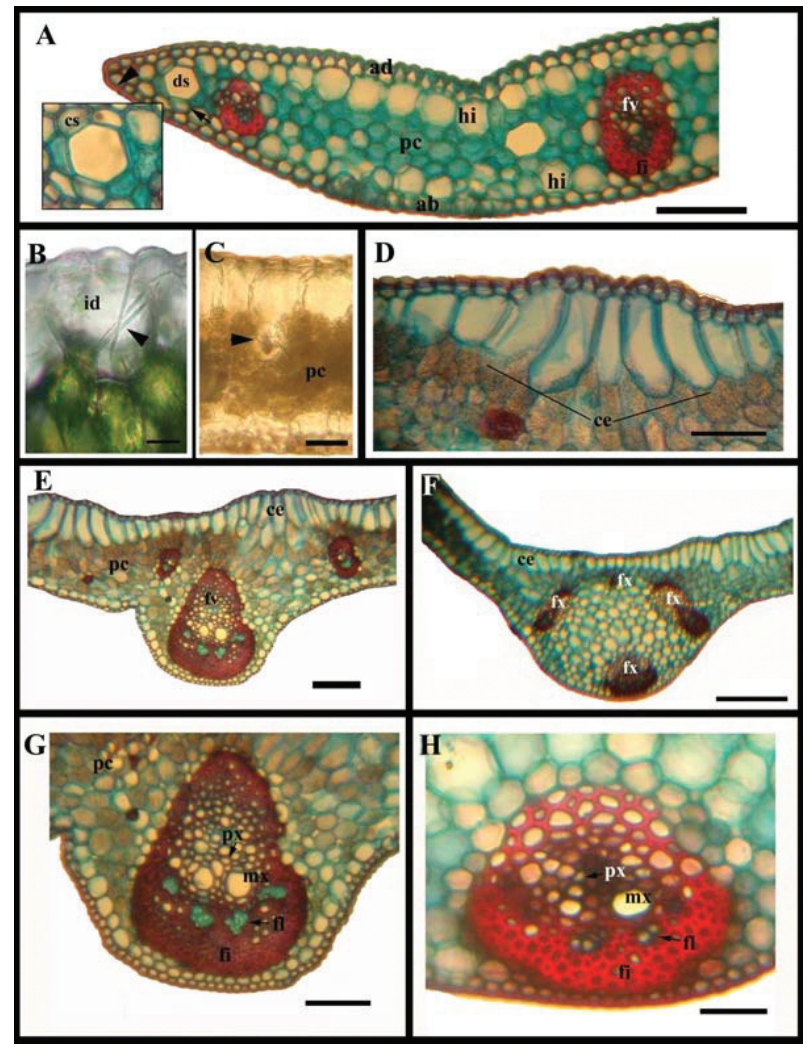

Figure 2. Transversal sections of leaves from oil palm seedlings under in vitro and greenhouse conditions. (A) a general view of leaf sheath showing hypodermis (hi) with more developed cells on the adaxial surface, homogenous chlorenchyma (pc), vascular bundles (fv) surrounded by sclerenchyma fibers (fi), secretory ducts (ds) limited by secretory cells (cs) and thickened cuticle in the leaf edge region (arrow). (B and C) raphides (arrow) on hypodermis cells and chlorenchyma (pc), respectively. (D) expansion cells (ce). (E) large tapered vascular bundle (fv) of the central midrib of leaves from greenhouse oil palm seedlings. (F) vascular bundles (fv) of the central midrib of leaves from in vitro oil palm seedlings. ( $\mathbf{G}$ and $\mathbf{H}$ ) detail of vascular bundles of leaves from in vitro and greenhouse oil palm seedlings, respectively, with floem (fl) distributed in isolates groups, metaxylem (mx), protoxylem (px), and fibers (fi) that form a dense sclerenchyma sheath bundles. Bars: A and F: $50 \mu \mathrm{m}$; B, C, E and G: $100 \mu \mathrm{m} ; \mathrm{D}: 20 \mu \mathrm{m}$.

Near the vascular bundles of the midrib, on the adaxial surface and below the epidermis, there is the occurrence of a layer of palisaded, elongated and distinct parenchyma cells (Figure 2D and F), called bulliforms by Esau (1974) and considered an expansion tissue by Tomlinson (1990). According to the latter author, this expansion tissue is responsible for furling and unfurling of the leaves in situations of water deficit, to prevent excessive water loss throughout the leaf surface. In $E$. guineensis, this tissue showed significantly greater length on plants grown in the greenhouse compared with those grown in vitro (Table 1). 
The mesophyll is comprised of chlorenchyma of the homogeneous type with few intercellular spaces, presenting three to four layers of cells with isodiametric shape (Figure 2). The thicker the chlorenchyma, the more resistant the plant is to pathogens. Furthermore, the compact parenchyma interferes with the distribution of carbon, which implies in lower photosynthetic efficiency (Akin an Robinson, 1982).

Secretory ducts (Figure 2) have been found between the parenchyma cells, distributed along the leaf blade in both growth conditions. These ducts are isodiametric, with no apparent content and demarcated with a layer of polyhedral secretory cells (Figure 2). The thickness of the leaf sheath on plants grown in a greenhouse was significantly higher (Table 1) than that of plants grown in vitro, which resulted from the sum of a thicker expansion tissue and thicker chlorenchyma.

In cross sections, the main vein of leaves in both environments is convex on the abaxial surface convex and flat on the adaxial surface. In the greenhouse-grown plants, the main vein has only one large tapered vascular bundle (Figure $2 \mathrm{E}$ ) with phloem also distributed in isolated groups (Figure $2 \mathrm{G}$ ). Regarding the in vitro plants, their vascular system is comprised of three to four collateral vascular bundles (Figure $2 \mathrm{~F}$ ), and the largest has phloem distributed in isolated groups (Figure $2 \mathrm{H}$ ) while the others are oval and have only one bundle of phloem.

In both conditions, the vascular bundles exhibit phloem positioned toward the abaxial surface and xylem disposed toward the adaxial surface, surrounded by fibers that form a dense sclerenchyma sheath (Figure $2 \mathrm{G}$ and $\mathrm{H})$. By comparing the diameter of vascular bundles in both environments, it was found that the bundles of plants developed in a greenhouse are more developed than those found in the in vitro leaves (Table 1). El-Bahr et al. (2003) verified that Phoenix dactylifera L. cv. Zaghlool, obtained by in vitro propagation, showed vascular tissues that were less developed and less differentiated than those from plants grown and acclimatized in ex vitro environments. This is also in line with the notion that plants grown in greenhouses or in field conditions are usually anatomically different from those maintained in vitro (Wetzstein et al., 1981). Indeed, it has been postulated that several environmental factors can affect the size and arrangement of the vascular elements, and these changes are evolutionary adaptations related to the maintenance of the transport capacity when the plant is subject to some kind of stress (Alves and AngyalossyAlfonso, 2000).

\section{CONCLUSIONS}

Despite the higher values recorded to stomata density, thickness of epidermis and hypodermis, expansion cells and mesophyll of plants grown in greenhouse through cultivation of pre-germinated seeds; leaves of oil palms developed the same tissue composition under both conditions of cultivation, and the seedlings formed by embryo rescue, at seven months of development are ready to be successfully acclimatized.

Important information can be obtained by exploring these anatomical aspects and the related physiological impact on the oil palm seedlings development, as it could be useful for studies of palm acclimatization, a limiting step in general breeding programs that use embryo rescue.

Acknowledgments: The authors thank the Conselho Nacional de Desenvolvimento Científico e Tecnológico (CNPq), Brasília, DF, Brazil, for financial support and fellowships, and Embrapa Amazônia Ocidental, Manaus, AM, Brazil, for providing the biological material for experiments.

\section{REFERENCES}

Adam H, Jouannic S, Escoute J, Duval Y, Verdeil JL, Tregear JW (2005) Reproductive developmental complexity in the African Oil Palm (Elaeis guineesis, Arecaceae). Am J. Bot. 92:1836-1852.

Akin DE, Robinson EL (1982) Structure of leaves and stems of arrowleaf and crim son clovers as related to in vitro digestibility. Crop Sc. 22:24-29.

Alves ES, Angyalossy-Alfonso V (2000) Ecological trends in the wood of some brazilian species 1: growth rings and vessels. lawa J. 21:3-30.

Barcelos E, Amblard P, Berthaud J, Seguin M (2002) Genetic Diversity and relationship in American and African oil palm as revealed by RFLP and AFLP molecular markers. Pesq. Agr. Bras 37:1105-1114.

Bone RA, Lee DW, Norman JM (1985) Epidermal cells functioning as lenses in leaves of tropical rain-forest shade plants. App. Optics 24:1408-1412.

Bosabalidi AM, Kofidis G (2002) Comparative effects of drought stress on leaf anatomy of two olive Cultivars. Plant Sci 163:375-379.

Chaimsohn FP, Montiel M, Villalobos E, Urpí JM (2008) Anatomía micrográfica del folíolo de la palma neotropical Bactris gasipaes (Arecaceae). Rev. Biol. Trop. 56:951-959.

Chia GS, Lopes R, Cunha RNV, Rocha RNC (2009) Germinação in vitro de pólen de híbridos interespecíficos entre 0 caiaué e o dendezeiro. Ciência Rural 39:1569-1561.

El-Bahr MK, Ali ZA, Taha HS (2003) In vitro propagation of Egyptian date palm cv. Zaghlool: II. comparative anatomical studies between direct acclimatized 
and in vitro adapted (pre-acclimatized) plantlets. Ar. Univ J. Agric. Sci. 11:701-714.

Ellis RP (1976) A procedure for standardizing comparative leaf anatomy in the Poaceae. I. The leaf blade as viewed in transverse section. Bothalia 12:65109.

Esau K (1972) Anatomia vegetal. Omega, Barcelona, España, 772p.

Esau K Anatomy of seed plants (1977). 2nd ed. New York, John Wiley and Sons, Inc., 550p.

Ghouse AKM, Yunus M (1972) Preparation epidermal peels from leaves of Gymnosperms by treatment with hot $60 \% \mathrm{HNO}_{3}$. Stain techn. 47:322-324.

Henderson FM (2006) Morphology and Anatomy of Palm Seedlings. Bot. Rev. 72:273-329.

Hu CY, Ferreira AG (1998) Cultura de embriões. In: Torres AC, Caldas LS and Buso JA (Eds.). Cultura de tecidos e transformação genética de plantas. Embrapa Informação Tecnológica, Brasília, p. 371-393.

Jourdan C, Rey H (1997) Architecture and development of the oil-palm (Elaeis guineensis Jacq.) root system. Plant Soil 189:33-48.

Konan EE, Durand-Gasselin T, Kouadio JY, Flori A, Rival AA (2006) Modeling approach of the in vitro conversion of oil palm (Elais guineensis) somatic embryos. Plant Cell Tiss Org Cult. 84:99-112.

Kraus JE, Arduin M (1997) Manual básico de métodos em morfologia vegetal. EDUR, Seropédica, 198p.

Lee DW, Oberbauer SF, Krishnapilay B, Mansor M, Mohamad H, Yap SK (1997) Effects of irradiance and spectral quality on seedling development of two Southeast Asian Hopea species. Oecologia 110:1-9.

Muchow RC, Sinclair TR (1989) Epidermal conductance, stomatal density and stomatal size among genotypes of Sorghum-bicolor (L.) Moench. Plant Cell Envir. 12:425-431.
Nunes CD, Lima D, Cunha RNV (1998) Germinação de sementes de dendê (Elaeis guineensis Jacq.), utilizando o método de calor seco. Manaus: Embrapa Amazônia Ocidental, 3p.

Pearce DW, Millard S, Bray DF, Rood SB (2005) Stomatal characteristics of riparian poplar species in a semi-arid environment. Tree Phys. 26:211218.

Rathi AS (1998) Role of leaf cuticular thickness in resistance against powdery mildew disease in peas. Indian J. Puls. Res. 11:136-137.

Scherwinski-Pereira JE, Guedes RS, Fermino Jr. PCP, Silva TL, Costa FHS (2010) Somatic embryogenesis and plant regeneration in oil palm using the thin cell layer technique. In Vitro Cell. Dev. Biol.-Plant 46:378-385.

Scherwinski-Pereira JE, Maciel TMS, Costa FHS, Pereira MAA (2006) Germinação in vitro de embriões zigóticos de murmuru (Astrocaryum ulei). Ciênc. Agrot. 30:251-256.

Silva LM, Alquini Y, Cavallet VJ (2005) Inter-relações entre a anatomia vegetal e a a produção vegetal. Acta Bot. Bras. 19:183-194.

Stauffer FW, Asmussen CB, Henderson A, Endress PK (2003) A revision of Asterogyne (Arecaceae: Arecoideae: Geonomeae). Brittonia 55:326-356.

Tomlinson PB The structural biology of palms (1990) New York: Oxford University Press, 477p.

Wetzstein HY, Sommer HE, Brown CL, Vines HM (1981) Anatomical changes in tissue cultured sweet gum leaves during hardening off period. Hortscience 16:290.

Zona S (2004) Raphides in palm embryos and their systematics distribution. Ann. Bot. 93:415-421. 